\title{
About Local Rules of Law of Modern Russian Legislation
}

\section{Vladimir Valentinovich Kozhevnikov}

Department of Theory and History of State and Law, Omsk State University Dostoevsky, Omsk, Russia Email: kta6973@rambler.ru

\begin{abstract}
:
This scientific article is devoted to the problems of local norms of modern Russian law: its features, necessity and classification. Attention is drawn to those local rules of law that must necessarily be in enterprises. It is noted that the scope of the former is not limited only to the scope of labor law.
\end{abstract}

\section{Keywords:}

local legal norms; labor law; internal labor regulations; Soviet legal science

\section{Introduction}

We believe that the relevance of local legal norms is due to the fact that the former mainly regulate the most important sphere of social relations - labor. Moreover, the first is explained by the fact that often local legal regulation is unreasonably identified with local and departmental regulation, and local legal norms - with corporate ones.

\section{Research Methods}

When preparing a scientific article, the following methods were used:

\section{General Philosophical (Dialectical-Materialistic)}

General Philosophical (Dialectical-Materialistic), which is used in all social sciences;

1. General scientific (analysis and synthesis, logical and historical, comparisons, abstractions, etc.), which are used not only by the theory of state and law, but also by other social sciences;

2. Special methods (philological, cybernetic, psychological, etc.), developed by special sciences and widely used for the knowledge of state and legal phenomena;

3. Private scientific (formal legal, interpretation of law, etc.), which are developed by the theory of state and law.

\section{Discussion}

\subsection{Local Norms of Law in the Soviet Legal Science}

An analysis of domestic legal literature shows that in the Soviet period of development of our society, certain attention was paid to local legal norms. It seems that this was largely due to the fact that at the turn of the 80-90s. in the system of socialist social relations, subject to the mechanism of legal regulation, the following socio-legal situation has developed: at the level of enterprises (associations) and organizations, a set of normative legal acts was formed, which, along with the current legislation, legally ensured the interests of the development of production and management relations of these enterprises (associations) and organizations, which theoretically made it possible to talk about a local legal complex. As Venir Kalimullovich Samigullin believes, "the norms forming this complex not only solved the problem of" additional regulation "in terms of concretizing the law and filling gaps in the law, 


\section{Britain International of Humanities and Social Sciences (BIoHS) Journal \\ ISSN: 2685-3868(Online), 2685-1989(Print) \\ Vol. 3, No. 1, February 2021, Page: 50-59}

but also carried out full-fledged legal public relations quite independently, sometimes even outstripping the development of the current legislation (especially in the field of labor, its payment, stimulation of labor activity of workers and employees, other working groups of the population, ensuring the profitability (profitability) of enterprises, contractual relations) "[1]. In domestic jurisprudence, for the first time, Nikolai Grigorievich Aleksandrov spoke out quite clearly more than half a century ago: "The norms of labor law established by law, decree or government decree are concretized in relation to the tasks and conditions of an individual enterprise in special local acts ..." [2]. Local acts were originally understood as the result of rule-making by organizations, enterprises, institutions in the field of labor relations. So, Radomir Ivanovich Kondratyev, considering local norms of labor law, believed that in the system of socialist norms of law, local norms occupy a special place, the action of which, as a rule, is limited to the framework of individual enterprises (institutions, organizations) and which apply to employees of a given production collective. Noting that a local rule of law, having all the features of a legal norm (general nature, guarantees from the state, etc.), has a number of specific features: a) specifies the rule of general action in relation to local conditions; b) is accepted only in cases and is valid within the limits specified by the legislator; c) has a limited scope that does not go beyond the limits of a particular enterprise; c) is accepted by the administration in agreement with the FZMK of the trade union [3]. It seems that in the context of these provisions, the position of Sergei Sergeevich Karinsky is of interest, who argued that the local norm acting on the scale of the enterprise concretizes and details the general and sectoral norms established in a centralized manner; as a result of concretization, a new norm appears, more detailed in comparison with the basic rule; local norms are obligatory for a personally indefinite (albeit limited) circle of persons who are in labor legal relations with this enterprise [4]. At the same time, it was justly noted that a local normative act is of a subordinate nature and should not contradict the normative legal acts of the higher authorities and administration [5]. By the way, let us note that even today there is an unjustified point of view, according to which the concept of "local normative legal acts" should be replaced with the normative legal acts of the employer containing the norms of law "'6.].

The modern theoretical scientist Venir Kalimullovich Samigullin emphasized that "local norms are more specific than general norms"; “... Those authors are right who draw attention to the fact that an essential feature of local legal norms is the following feature action in a circle of persons" [1.].

Scientists noted that "the need for the existence of local norms along with legal ones of general importance is explained by the fact that the latter (due to their general nature) cannot always be applied to those social relations, including labor relations, certain types of which at specific enterprises are distinguished by significant diversity" [1].

In his other works, recognizing that in the science of labor law, local is called the legal regulation of labor relations based on the law and carried out directly by enterprises (production associations, combines), some aspects of which within a particular production have local, specific features, Radomir Ivanovich Kondratyev emphasized, that "... a local norm is necessary only where, due to certain specific conditions, it is impossible to apply a single general rule" [7], that "it is with the help of local norms of law that one can take into account the peculiarities of labor of one or another category of workers at a particular enterprise" [8 ]. Frida Markovna Leviant, pointing out that "there is a need for the norms of law that take into account the relevant conditions of a particular production collective - in local norms of law," the latter interpreted as rules of generally binding behavior, sanctioned and protected by the 
state, adopted on an equal footing in conciliation contractually by a production and labor collective headed by its administration and a professionally organized collective of workers and employees represented by FZMK in order to regulate certain rights and obligations of members of this collective [9]. Later, other Soviet legal theorists also turned to the analysis of local norms. For example, Lyudmila Ivanovna Antonova interprets the local norm as follows: "this is the norm of socialist law, adopted directly at the enterprise in order to implement its special legal personality (I think that it is more correct, legal capacity - Vladimir Valentinovich Kozhevnikov). By the administration within its competence with the active participation of the trade union committee or by the labor collective itself in accordance with the powers granted to it, regulating, in addition to national norms, labor or organizational and managerial relations at the enterprise and acting within it "[10]. Sergei Ivanovich Arkhipov, referring to the analysis of local norms of law, believes that these norms, like any other norms of law, are applied (or rather, implemented - Vladimir Valentinovich Kozhevnikov ) repeatedly, are addressed to not personally defined subjects, are supported by the force of state coercion. The author paid attention to the fact that in the system of Soviet law these norms occupy the lower level, and in terms of their legal force they are inferior to all other varieties of norms. These are state-sanctioned rules developed in the process of "autonomous" regulation of internal issues by the organization [11].

At one time, Sergei Sergeevich Alekseev, taking into account that local legal norms are established and operate within the framework of separate independent organizations, called them organizational $[12 ; 13]$.

\subsection{Local Norms of Law in Modern Legal Science}

An analysis of modern educational legal literature shows that when classifying legal norms, scientists either do not mention the existence of local legal norms at all, or show insufficient attention to their analysis, limiting themselves to a few phrases. For example, Lyudmila Aleksandrovna Morozova, highlighting local norms, emphasizes that they are adopted at individual enterprises, firms, public organizations, etc. and operate only within this organization (for example, internal labor regulations, regulations on holding competitions, etc.) [14]. At one time, Mikhail Iosifovich Baytin, highlighting local ones among legal norms, wrote in relation to the latter that they "... act within a separate state, cooperative organization or their structural divisions, express the nature, goals and specifics of the activities of a particular labor collective, a certain public association are aimed at stimulating and streamlining this activity "[15]. Local normative prescriptions are asserted by Robert Vachaganovich Yengibaryan and Yuri Konstantinovich Krasnov, "these are the norms established by individual state, public or private structures for themselves" [16].

In the context of these provisions, it is difficult to understand the position of Nikolai Mikhailovich Chistyakov, who, extending the norms of local action to individual state, public and private structures, claims that we are talking about charters, instructions adopted by ministries and departments for intradepartmental use [17]. Considering that the nature, goals, task and specificity of the activities of a specific team of an organization are recorded in local norms of law, it is noted that such norms operate within a separate state, business, political, cultural, public and other organizations or their structural divisions [18], Mikhail Iosifovich Baytin categorically asserted that the norms under consideration operate within a separate state, private, cooperative, other public organization or its structural units, express the nature, goals and specifics of the activities of a particular work collective, are aimed at stimulating and streamlining this activity [19]. Running a little ahead, we note that in relation to these norms, the point of view of Ivan Andreevich Ivannikov is most correct, who, narrowing the scope of 
local norms of law, believes that they " $\ldots$ act only within individual state organizations or structural divisions and regulate the specific activities of this labor collective "[20.].

Apparently, Valery Vasilyevich Lazarev and Sergey Vasilyevich Lipen are talking about local norms of law, believing that there are norms of law of external and internal action in the sphere of action; the latter, being adopted by the relevant state body or organization, act only within the framework of this body, department, enterprise, organization [21]. Ignoring this property of local rules of law objectively leads Roman Anatolyevich Romashov to the controversial statement that the latter "operate within a separate territorial entity (these include the rules of conduct enshrined in regulatory acts adopted and operating in the territories of the subjects of the Russian Federation, municipalities, etc.) .p. "[22], which, as you know, firstly refer to local regulatory legal acts; secondly, they mainly have an external effect. In Soviet times, Sergei Ivanovich Arkhipov defended the position according to which" local are also normative acts of local Councils, their executive committees and other organizations. "[23] In other words, the author also did not distinguish between local and local legal regulation.

From the standpoint of Viktor Dmitrievich Perevalov, "local regulatory prescriptions operate within the framework of individual state, public or private structures" [24]. Valery Nikolaevich Protasov and Natalya Valerievna Protasova also write in a very laconic form that "local (intra-organizational) legal norms are norms that operate within a certain organization and apply only to its members" [25].

Local norms, as well as local regulatory legal acts, differing in a number of specific legal features, have recently become the subject of careful consideration in legal science.

Thus, Tatyana Aleksandrovna Pytikova and Svetlana Vladimirovna Boshno believe that local legal acts have the following essential features: volitional content, intraorganizational nature, subordinate nature, dynamism and stability, multiple application, duration of existence, obligation for addressees of norms, support by coercive power of the state. Referring to such a feature of them as a subordinate character (a character derived from legislation), the author rightly argues that all local acts arise by virtue of the direct indication of the law, indicating that a local legal act should be adopted on this issue. As one of the examples, the following is given: organizations (taking into account their production and financial capabilities) can independently establish additional vacations, unless otherwise provided by federal laws. The procedure and conditions for the provision of these leaves are determined by collective agreements or local regulations, which are adopted taking into account the opinion of the elected body of the primary trade union organization. (Article 116 of the Labor Code of the Russian Federation) [26].

\subsection{Local Norms of Law Enshrined in Russian Legislation}

At present, at the rule-making level, local norms are mainly enshrined in labor regulations (Articles 8, 12, 15, 20, 22, 26, 33, 53, 56, 57, 59, 68, 70, 74, 80, 81, 88, 94, 96, 97, 101, 105, 112, etc. of the Labor Code of the Russian Federation) legislation and legislation on education (Articles 13, 32, 50 of the RF Law of July 10, 1992 "On Education "). Thus, Mikhail Petrovich Petrov believes that "without the transfer of part of the legal means to the level of local regulation, educational relations will lose flexibility and efficiency" [27]. Analyzing relations in the same area, Alexander Nikolaevich Kozyrin and Tatyana Nikolaevna Troshkina emphasize the special importance of local regulations, since they take into account the opinions of employees of educational institutions "[28]. 
Noting that other normative acts speak of the adoption of local acts on the implementation of any functions by various departments, the implementation of the target program, the procedure for the work of the media, etc., emphasizing that the understanding of local acts (and norms - Vladimir Valentinovich Kozhevnikov) should not reduced exclusively to the scope of labor law, Eduard Aleksandrovich Rubailo argues that they are aimed at solving a wider range of internal organizational issues - from defining the goals of the organization as such in the charter to fixing the list of information constituting a commercial secret, etc. [29].

It seems that the local regulation of social relations, carried out with the help of appropriate norms, can be characterized as regulation designed to unite, on the one hand, national centralized regulation and, on the other hand, the activities of various kinds of enterprises, organizations, institutions for the independent solution of intra-organizational issues. It seems that in this regard it is appropriate to cite the position of Grigory Naumovich Manov, who at one time wrote the following: "as for economic organizations and their governing bodies, no one disputes that their initiative and entrepreneurial spirit cannot manifest themselves only" in the grip "of a tough legal regulation. These subjects of law use a wide arsenal of tools that allows them to solve multifaceted tasks "[30].

\subsection{About the Need For Local Regulations in Labor Law}

Oleg Mikhailovich Krapivin and Vasily Ivanovich Vlasov point to a number of circumstances that predetermine the need to regulate labor relations through the adoption of local normative legal acts: firstly, they are adopted when any labor relations actually exist, but are not entered into the framework of legislative regulation, that is, there is a gap in the legislation; secondly, they are developed in cases when it is necessary to normalize the procedure for applying legislative and other regulatory legal norms: thirdly, the need for local regulatory acts arises when a certain area of labor relations is regulated by several (many) legal acts; in this case, it is advisable to state them in a certain sequence in any one normative act (for example, in the internal labor regulations); fourthly, without their use, the employer cannot pursue an active and effective personnel development policy in relation to the constantly changing market conditions; fifth, the employment relationship between the employee and the employer is individualized through the conclusion of an employment contract between them, which cannot cover all relations arising in the course of the employee's employment with the employer; sixth, local regulations (regulations, instructions, rules) are documents, the content of which is communicated by the employer to the employee as a guide that employees are required to follow; at the same time, local regulations are a source of knowledge for workers about their labor rights [31].

\subsection{About the Classification of Local Regulations}

Agreeing with the position of scientists that the nature of local rules of law derived from legislation is manifested in the fact that they arise by virtue of the direct indication of the law [26], there is no exact list of local regulations, as there is no indication of which of them are mandatory.

Meanwhile, in the legal literature, various classifications of local regulations are proposed. So, Marina Leonidovna Davydova, defining the latter as internal acts of various legal entities, proposes to classify the relevant acts on various grounds: 1) by meaning: a) universal, that is, those that are mandatory for any legal entity (for example, constituent documents) and b) specific, characteristic of certain types of organizations (for example, the program of a political party); 2) according to the degree of obligation: a) mandatory, i.e. acts that the organization must adopt and b) optional (for example, according to Article 9 of the 
Labor Code of the Russian Federation, the presence of a collective agreement at each enterprise is not mandatory); 3) according to the order of adoption: a) adopted by the general meeting (memorandum of association, collective agreement, charter, regulation, program, etc.) and b) governing bodies, which, as a rule, are made dependent on the content of contractual acts (for example, according to article 8 of the Labor Code of the Russian Federation "the employer adopts local regulations containing legal norms, within the limits of its competence in accordance with laws and other regulations, collective bargaining agreements, agreements"; 4) depending on the content and target orientation: a) regulating internal organizational issues and b) defining goals, directions, program of external activities (for example, programs of political parties); 5) in accordance with the object of legal impact: a) regulating relations between participants (members, founders) of the organization and b) establishing the legal status of employees; 6) by legal meaning: a) primary, which are directly subject to state registration and are the legal basis of the organization's activities and b) secondary, based on primary and not contradicting them [32].

\subsection{Mandatory Local Norms Of Law In Labor Law}

It seems that in relation to the regulation of labor relations, it is possible to single out conditionally mandatory local norms of law, that is, those whose presence is enshrined in the Labor Code: internal labor regulations, regulations on the processing of personal data of employees, regulations on labor protection, etc. It should be borne in mind that there may be several ways to formalize the requirements of labor legislation, hence the variability in the list of documents. For example, the Labor Code of the Russian Federation spelled out the requirement to identify the main labor functions when hiring a person. The employer can do this in two ways: write them into the employment contract or familiarize the new employee with the job description. In addition, the specifics of the activities of the enterprise or certain categories of its employees are also of great importance: work requiring a mandatory medical examination, activities related to commercial secrets, etc. In such a situation, it is very important to determine which of the documents are mandatory for the employer and which are optional. complicated.

We believe that local regulations, which apply to the entire team or to certain categories of employees, which must be adopted by employers in order to regulate labor relations with an employee, are as follows:

- Internal labor regulations, which, according to Part 4 of Art. 189 of the Labor Code of the Russian Federation, are interpreted as "a local normative act regulating, in accordance with this Code and other federal laws, the procedure for hiring and dismissing employees, the basic rights, obligations and responsibilities of the parties to an employment contract, working hours, rest time, incentives and penalties applied to employees, as well as other issues of regulation of labor relations with this employer. " Be aware that the law does not establish any requirements for the content of the internal regulations. In each case, it is determined at the discretion of the organization itself. When developing internal labor regulations in an organization, the Standard Internal Labor Regulations for workers and employees of enterprises, institutions, organizations, approved by the USSR State Committee of Labor in agreement with the All-Union Central Council of Trade Unions of July 20, 1984 [33], can be used as an example.

- Regulations on commercial secrets. In accordance with. Part 1 of Article 11 "Protection of confidentiality of information constituting a commercial secret within the framework of labor relations" of the Federal Law of July 29, 2004 "On commercial secrets", "in order to protect the confidentiality of information constituting a commercial secret, the employer must: 1) inform a receipt of the employee, whose access to this information, which is owned by the employer and his counterparties, is necessary for the employee to fulfill his 
job duties, with a list of information constituting a commercial secret; 2) to familiarize the employee, on receipt, with the trade secret regime established by the employer and with the measures of responsibility for its violation; 3) create the necessary conditions for the employee to comply with the trade secret regime established by the employer".

- Job descriptions. In the letter of the Federal Service for Labor and Employment dated August 9, 2007. states the following: "The Labor Code does not contain any mention of job descriptions, although job descriptions are an integral tool for regulating labor relations. This is not just a formal document, but a document that defines the tasks, qualifications, functions, rights, duties, and responsibilities of the employee. It seems that job descriptions should be developed for each position (including the vacant one) available in the staffing table.

The job description is necessary both in the interests of the employer and the employee. So, the absence of a job description in some cases prevents the employer from making a justified refusal to hire (since it may contain additional requirements related to the employee's business qualities), objectively assess the employee's activities during the probationary period, distribute labor functions between employees, temporarily transfer the employee to another job, assess the conscientiousness and completeness of the employee's work function.

The basis for the development of job descriptions is the qualification characteristics contained in the Unified Qualification Handbook of the Positions of Managers, Specialists and Employees. The job description can be either an annex to the employment contract or be approved by the employer as a separate document. In itself, the absence of a job description should not be regarded as a violation of labor legislation and entail responsibility, however, it can have negative consequences in the form of unlawful decisions made by the employer due to its absence".

- Regulation on remuneration of employees, Regulation on bonuses and material incentives for employees. (Section VI "Remuneration and regulation of labor" of the Labor Code of the Russian Federation).

- Regulation on the processing of personal data of employees. In Art. 86 of the Labor Code of the Russian Federation "General requirements for the processing of personal data of employees and guarantees of their protection", the general principles underlying the processing of personal data by the employer or his representative are established, the purposes of the processing of personal data of the employee are determined: compliance with laws, other regulatory legal acts, assistance in employment, training and promotion, ensuring the personal safety of employees, monitoring the quantity and quality of work performed and ensuring the safety of property.

In implementing the general requirements for the processing of personal data, enshrined in this article, the employer must be based on the principles of processing personal data enshrined in Art. 5 of the Law on Personal Data of July 27, 2006: the legality of the purposes and methods of processing personal data and good faith; compliance of the purposes of processing personal data with the goals predetermined and declared when collecting personal data, as well as the powers of the operator (employer); correspondence of the volume and nature of the processed personal data, methods of processing personal data to the purposes of processing personal data; the reliability of personal data, their sufficiency for the purposes of processing, the inadmissibility of processing personal data that are redundant in relation to the purposes stated when collecting personal data; inadmissibility of combining personal data information systems created for incompatible databases. Within the meaning of the content of Art. 88 of the Labor Code of the Russian Federation "Transfer of personal data 
of an employee" the employer must adopt a local regulatory act governing the procedure for the transfer of personal data of an employee within one organization.

- Regulations on labor protection (section X "Labor protection" of the Labor Code of the Russian Federation).

- Instructions on electrical safety, fire safety and labor protection (section X of the Labor Code of the Russian Federation). In the commentary part 1 of Art. 211 of this section states that, as its content follows, the state regulatory requirements for labor protection are contained in federal laws and other regulatory legal acts of the Russian Federation, in laws and other regulatory legal acts of the constituent entities of the Russian Federation and establish rules, procedures and criteria aimed at preserving the life and health of employees in the process of work.

Labor protection requirements in accordance with Part 10 of Art. 209 of the Labor Code of the Russian Federation are contained in the rules and instructions on labor protection, approved, as a general rule, by the employer, taking into account the opinion of the elected body of the primary trade union organization or other body authorized by employees in the manner prescribed by Art. 372 of the Labor Code of the Russian Federation. These requirements are stated in relation to the position, profession of the employee or the type of work performed [34].

- Staffing table. (Resolution of the State Statistics Committee of the Russian Federation of 05.01.2004 N 1 "On approval of unified forms of primary accounting documentation for labor accounting and remuneration)." In a letter from the Federal Service for Labor and Employment dated May 15, 2014 "On the employer's right to acquaint employees with the staffing table when hiring," it also states that the staffing table is included in the group of local regulations.

- Vacation schedule. In accordance with Part 1 of Art. 123 of the Labor Code of the Russian Federation, "the order of granting paid vacations is determined annually in accordance with the vacation schedule approved by the employer, taking into account the opinion of the elected body of the primary acts ". This local normative legal act is mentioned in the Decree of the State Statistics Committee of the Russian Federation dated January 5, 2004 "On the approval of unified forms of primary accounting documentation for labor accounting and remuneration."

The list of local regulations can be supplemented by provisions on vacations, business trips, personnel certification, etc. in accordance with the needs of the employer. Anton Leonidovich Anisimov, in addition to some of the above local regulatory legal acts (on the procedure for transferring personal data of an employee, on the priority of granting paid vacations), draws attention to other local acts, which the employer must adopt: 1) in accordance with Part 8 Art. 94 of the Labor Code of the Russian Federation for certain categories of creative workers, the duration of daily work (shift) can be established by local regulations without taking into account the opinion of the representative body of workers; 2) in accordance with Part 6 of Art. 96 of the Labor Code of the Russian Federation, the procedure for working at night for the creative workers indicated in it may be determined by a collective agreement, a local regulatory act or an agreement of the parties to the employment contract; 3) in accordance with Art. 105 of the Labor Code of the Russian Federation, the division of the working day into parts is carried out on the basis of a local regulatory legal act, adopted taking into account the opinion of the trade union body of this organization; 4) as follows from Part 2 of Art. 116 the employer can independently establish additional holidays for employees in accordance with the collective agreement or local regulations adopted by the head of the organization without taking into account the opinion of the trade union committee [35]. 


\section{Conclusion}

In conclusion, we note that the existence of local norms of modern Russian legislation, which have their own specific features, is due to the autonomy, relative independence of enterprises, which, by adopting such norms, regulate a complex of certain labor relations. Although it should be borne in mind that the scope of their distribution is not limited only to the scope of labor law.

\section{References}

[1]. Samigullin Venir Kalimullovich. Local normative legal regulation: state and prospects // Journal of Russian law. 2016. No. 4. Pp.8, 18, 21.

[2]. Alexandrov Nikolay Grigorievich. Labor relations. M .: Jurid. Publishing house of the USSR Ministry of Justice, 1948. P. 66

[3]. Kondratyev Radomir Ivanovich. Local labor law and material incentives. Lvov: Vishcha school, 1973.Pp. 8, 9

[4]. Karinsky Sergey Sergeevich. The ratio of centralized and local methods of legal regulation of labor remuneration // Jurisprudence. 1971. No. 5. Pp.47-56

[5]. Tarasova Valentina Alexandrovna. Subject and concept of local law // Jurisprudence. 1986. No. 4. P.94

[6]. Ershova Elena Alexandrovna. Sources and forms of labor law in the Russian Federation: author. dis ... doct. jurid. sciences. M .: Moskov. state jurid. acad, 2008.P.34

[7]. Kondratyev Radomir Ivanovich. Combination of centralized and local legal regulation of labor relations: monograph. Lvov: Vishcha school, 1977.Pp. 8, 50-51

[8]. Kondratyev Radomir Ivanovich. General and special in labor relations and issues of local rule-making / / Jurisprudence. 1971. No. 5. P. 42

[9]. Leviant Frida Markovna. On the legal nature of local legal norms governing labor relations at industrial enterprises // Jurisprudence. 1970. No. 5. Pp.65, 66

[10]. Antonova Lyudmila Ivanovna. Local legal regulation (theoretical research): monograph. L .: Leningrad Publishing House. un-that, 1985. P.79

[11]. Arkhipov Sergey Ivanovich. The concept and legal nature of local rules of law // Jurisprudence. 1987. No. 1. Pp.29, 32

[12]. Alekseev Sergei Sergeevich. Problems of the theory of law, vol. 1, Sverdlovsk: Sverd. jurid. inst., 1972.P. 249.

[13]. Alekseev Sergei Sergeevich. General theory of law in 2 volumes. M .: Jurid. literature, 1982.T. 2.P. 78.

[14]. Morozova Lyudmila Alexandrovna. Theory of state and law: textbook. M :: Eksmo, 2007.P. 233

[15]. Baytin Mikhail Iosifovich. Norms of law // Theory of state and law: a course of lectures / ed. Nikolai Ignatievich Matuzov and Alexander Vasilyevich Malko. M.: Yurst 2007.P. 372

[16]. Engibaryan Robert Vachaganovich, Krasnov Yuri Konstantinovich. Theory of state and law: textbook), Moscow: Norma, 2010. P.388

[17]. Chistyakov Nikolai Mikhailovich. Theory of state and law: textbook. M.: KNORUS, 2010. P. 134

[18]. Lyubashits Valentin Yakovlevich, Mordovtsev Andrey Yuryevich, Mamychev Alexey Yuryevich. Theory of state and law: textbook. Rostov n / D: Phoenix, 2010.P. 471

[19]. Baytin Mikhail Iosifovich. The essence of law (modern normative legal thinking on the verge of two centuries): monograph. Moscow: Ed. House "Law and State", 2005. P. 262 
[20]. Ivannikov Ivan Andreevich. General theory of state and law: textbook. M.: Ed. - trades. corporation "Dashkov and Co", 2008. P. 197

[21]. Lazarev Valery Vasilievich, Lipen Sergey Vasilievich. Theory of state and law: textbook. M .: Yurayt, 2010.P. 307

[22]. Roman Anatolyevich Romashov. Theory of state and law: a short course. SPb: Peter, 2010.P. 152

[23]. Arkhipov Sergei Ivanovich. Some issues of systematization of local legal norms // Legal theory and practice: problems of interrelation. Sverdlovsk, 1984.P. 118

[24]. Perevalov Viktor Dmitrievich. Norms and forms (sources) of law. System of law and system of legislation // Theory of state and law: textbook / otv. ed. Viktor Dmitrievich Perevalov. M .: Norma, 2007.P. 166

[25]. Protasov Valery Nikolaevich, Protasova Natalia Valerievna. Lectures on general theory of law and theory of the state. Moscow: Ed. House "Gorodets", 2010. P. 306

[26]. Pytikova Tatiana Alexandrovna, Boshno Svetlana Vladimirovna. Legal nature and signs of local legal acts // Lawyer. 2006. No. 5. Pp.7-9

[27]. Petrov Mikhail Petrovich. Local acts of the organization of education: legal nature, types and grounds for adoption // Yearbook of Russian educational legislation. 2014. Vol.9. P.7

[28]. Kozyrin Alexander Nikolaevich, Troshkina Tatiana Nikolaevna. Legal regulation in the field of education: scientific and practical commentary on article 4 of the Federal Law "On education in the Russian Federation" // Yearbook of Russian educational legislation. 2013. Vol. 8. Pp.22-23

[29]. Rubailo Eduard Alexandrovich. Local acts in the system of legal acts of the Russian Federation // Journal of Russian law. 2010. No. 5. P. 75

[30]. Manov Grigory Naumovich. Axioms in the Soviet theory of law // Sov. state and law. 1986. No. 9. P.32

[31]. Krapivin Oleg Mikhailovich, Vlasov Vasily Ivanovich. Employer: rights and responsibilities. M.: Norma, 2004. Pp. 77-78

[32]. Davydova Marina Leonidovna. Local normative legal acts in the system of Russian legislation: problems of concept and classification // "Black holes" in Russian legislation. 2008. No 2. Pp. 82-83.

[33]. Typical rules of internal labor regulations for workers and employees of enterprises, institutions, organizations, approved by the decree of the USSR State Committee for Labor in agreement with the All-Union Central Council of Trade Unions dated July 20, 1984 // Bulletin of the USSR State Committee for Labor. 1984. No. 11.

[34]. Comment on the Labor Code of the Russian Federation / otv. ed. Yuri Petrovich Orlovsky, Moscow: Jurid. firm "CONTRACT": "INFRA-M", 2008. P. 648

[35]. Anisimov Anton Leonidovich. Basic rights and obligations of the employer // Labor law. 2004. No. 3. Pp.64-65. 